\title{
Patrycja Błocisz
}

YES Biżuteria Sp z o.o.

e-mail: patrycjadolataa@gmail.com

\section{Elżbieta Kowalczyk}

Uniwersytet Ekonomiczny w Poznaniu

e-mail: e.kowalczyk@ue.poznan.pl

\section{ZARZĄDZANIE KAPITAŁEM LUDZKIM OPARTE NA KOMPETENCJACH ZAWODOWYCH PRACOWNIKÓW}

\section{HUMAN CAPITAL MANAGEMENT BASED \\ ON EMPLOYEES' PROFESSIONAL COMPETENCES}

DOI: $10.15611 / \mathrm{pn} .2018 .511 .02$

JEL Classification: M12

Streszczenie: Celem artykułu jest prezentacja założeń oraz określenie stanu wykorzystania koncepcji systemu zarządzania kompetencjami. Głównym problemem badawczym było poszukiwanie odpowiedzi na pytanie: jakie są zasady implementacji oraz opinie kierowników na temat funkcjonowania tego systemu? W związku z tym w części teoretycznej opracowania ukazano istotę kompetencji zawodowych oraz zasady i możliwości wdrażania systemu zarządzania kompetencjami. W części empirycznej zaprezentowano wyniki badań własnych, którymi objęto grupę 46 kierowników reprezentujących organizacje wykorzystujące ten system. Badania przeprowadzono z wykorzystaniem ankiety on-line i w ich wyniku ustalono, że kierownicy w większości go rekomendują, a w im większej liczbie obszarów jest on stosowany, tym dostrzegają więcej korzyści z jego stosowania. Równocześnie warunkiem umożliwiającym jego sprawne wdrożenie jest jasna komunikacja i zaangażowanie pracowników w proces implementacyjny.

Słowa kluczowe: kompetencje, system zarządzania kompetencjami, wdrażanie zmian.

Summary: The aim of this paper is to present the idea of competences management system. The main empirical problem was: what are the rules of implementation and managers' opinions on the functioning of competences-based management system. Therefore, the theoretical part shows the content of professional competences, the main rules and means of implementation the competences-based management system. In the empirical part of the article, the results of authors' own studies are presented. The survey covered 46 managers from organizations using this system. The research established that the majority of managers recommended the system, and if the greater the number of areas the organization used it, the more benefits they saw. The conditions of efficient implementation is efficacy communication and employees' engagement in the process of change implementation.

Keywords: competences, competences management system, changes implementation. 


\section{Wstęp}

System zarządzania kompetencjami jest jednym z rozwiązań z obszaru zarządzania kapitałem ludzkim (ZKL), który zyskuje coraz większe uznanie zarówno wielu praktyków, jak i naukowców. Służy on holistycznemu i zintegrowanemu zarządzaniu organizacją, której równoprawnym partnerem jest pracownik dysponujący niezbędnymi dla niej kompetencjami. Równocześnie z ogólnopolskich badań wynika, że w 67\% przypadków brak kompetencji w sposób znaczący (pośrednio lub bezpośrednio) wpływa na niższą konkurencyjność przedsiębiorstwa. Z pewnością z tego powodu jedynie $30,4 \%$ badanych przedsiębiorstw nie zamierzało wdrażać systemu zarządzania kompetencjami [Sienkiewicz, Trawińska-Konador, Podwójcic 2013, s. 38 i 45$]$.

Celem artykułu jest ukazanie istoty i założeń koncepcji systemu zarządzania kompetencjami oraz weryfikacja stopnia jego implementacji w praktyce biznesowej. Realizując tak postawiony cel, autorki w części teoretycznej opracowania ukazały istotę samych kompetencji analizowanego systemu oraz omówiły uwarunkowania jego wykorzystania w organizacjach biznesowych. Implementacja nowego rozwiązania wymaga praco- i czasochłonnego przygotowania zarówno kierowników, jak i pracowników. Jednakże, jak wynika z badań, którymi objęto kadrę zarządzającą przedsiębiorstw, a zaprezentowanych w części empirycznej artykułu, wysiłek ten jest opłacalny. Głównym problemem badawczym było poszukiwanie odpowiedzi na pytanie: jakie są teoretyczne zasady oraz opinie kierowników dotyczące funkcjonowania systemu zarządzania kompetencjami w przedsiębiorstwach?

\section{Kompetencje zawodowe na tle koncepcji zarządzania kapitałem ludzkim}

\subsection{Elementy ksztaltujące systemu zarządzania kompetencjami}

Literatura przedmiotu z zakresu kompetencji jest bogata i cechuje się wielorakością ujęć problematyki. Jednakże G. Filipowicz twierdzi, że mnogość koncepcji nie jest przeszkodą w ich wykorzystaniu w praktyce, jedynie wymaga ich dopasowania do potrzeb i celów konkretnej organizacji [Filipowicz 2014, s. 14-15]. Równocześnie S. Whiddett i S. Hollyforde podkreślają, że precyzja w definiowaniu kompetencji oraz unikanie wieloznaczności jest warunkiem niezbędnym do sprawnego funkcjonowania systemu zarządzania kompetencjami zawodowymi [Whiddett, Hollyforde 2003, s. 209]. Kompetencje przez wielu badaczy zajmujących się tą tematyką rozumiane są jako zestaw wiedzy (na którą składają się doświadczenie i formalna edukacja), umiejętności, postaw, wartości, osobowości i motywów [Kowlaczyk 2014]. Tę definicję autorki przyjmują do celów tego opracowania, równocześnie sprawdzając, w jakim stopniu te składowe są utożsamiane z sednem kompetencji przez kierowników. 
Ponadto autorzy zajmujący się problematyką kompetencji zawodowych w odmienny sposób dokonują ich kategoryzacji (m.in. [Filipowicz 2014; Sidor-Rządkowska 2011; Oleksyn 2006; Sienkiewicz, Trawińska-Konador, Podwójcic 2013]). W rezultacie dokonanego przeglądu literatury wyróżniono wśród nich takie, które są charakterystyczne dla wykonywanego zawodu, organizacji, zajmowanego stanowiska, kluczowe z punktu widzenia przewagi konkurencyjnej organizacji, oraz społeczne - gwarantujące dobre radzenie sobie w różnych, nie tylko zawodowych, sytuacjach. W oparciu o kategorie kompetencji można zbudować model kompetencyjny, definiowany m.in. jako ogół kompetencji uznany w organizacji za niezbędny do zdobycia przewagi konkurencyjnej i realizacji sformułowanych przez nią celów [Orlińska-Gondor 2006]. Powiązany z nim ściśle jest profil kompetencyjny, który określa wymogi na danym stanowisku pracy i służy m.in. w rekrutacji i doskonaleniu pracowników. Przy czym stworzony profil jest ściśle powiązany z organizacją, jej kulturą, przyjętą strategią rynkową, sektorem działalności. Ważne jest, by zawierał listę i definicję wszystkich kompetencji w nim ujętych, wymagany i aktualny poziom opanowania kompetencji oraz behawioralne wskaźniki pomocne w diagnozie stopnia ich posiadania przez pracowników [Rostkowski (red.) 2004]. Dzięki sporządzonym profilom organizacja jest w stanie w sposób systemowy zarządzać kompetencjami zawodowymi, czyli tak prowadzić politykę personalną, by kompetencje umożliwiły integrację wszystkich działań z zakresu zarządzania kapitałem ludzkim - od rekrutacji i selekcji, poprzez planowanie ścieżek karier, oceny, szkolenia, aż po wynagradzanie i awanse. System zarządzania kompetencjami rozumiany jest przez autorki jako proces z obszaru zarządzania kapitałem ludzkim, u którego podstaw leży identyfikacja potencjału kompetencyjnego pracowników, określenie aktualnych i prognozowanych potrzeb kompetencyjnych organizacji oraz identyfikacja luk kompetencyjnych wraz ze sposobem ich niwelacji. Z jednej strony służy on pracownikom, wspierając ich rozwój i budując ducha zespołu [Draganidis, Mentzas 2006], z drugiej umożliwia organizacji przewidywanie nadchodzących zmian oraz przygotowanie się na nie, czy to poprzez pozyskanie nowych, czy rozwój obecnych pracowników. Ważne jest, by był on bezstronny i obiektywny, uniemożliwiał praktyki dyskryminacyjne. Ponadto jasno sformułowany, o logicznej strukturze zbudowanej z niezależnych od siebie elementów składowych, zrozumiały dla każdego użytkownika oraz uwzględniający potrzeby i oczekiwania pracowników [Whiddett, Hollyforde 2003].

\subsection{Kompetencje z perspektywy koncepcji zasobowej i kapitalowej}

Ostatnią z rozważanych $\mathrm{w}$ tym podrozdziale kwestii jest próba rozstrzygnięcia dylematu związanego z rozumieniem kluczowego dla omawianej koncepcji pojęcia „kompetencji” - czy są one zasobem, czy kapitałem? I czym de facto zarządza organizacja? By znaleźć odpowiedź na tak postawione pytanie, należy zauważyć, że po pierwsze, w koncepcji zasobowej kompetencje są traktowane jako „własność” orga- 
nizacji, z której może ona, ale nie musi korzystać. Po drugie, zasoby jedynie mogą przyczyniać się do budowania przewagi konkurencyjnej, a pracownik, oddając do dyspozycji swoje kompetencje, ceduje odpowiedzialność za ich wykorzystanie i rozwój na pracodawcę. Po trzecie, kompetencje mogą być traktowane jako narzędzie umożliwiające wykorzystanie zasobów, co nie jest równoznaczne z byciem nimi. Z kolei w ujęciu kapitałowym kompetencje pracownika to aktywa, które ma do dyspozycji organizacja, służące jej rozwojowi i mające zdolność do namnażania się. J. Strużyna uważa, że koncepcja kapitału ludzkiego odpowiedzialnym za wykorzystanie potencjału kompetencyjnego posiadanego przez pracownika czyni zarówno jego samego, jak i organizację. Pracownik nie wszystkie swoje kompetencje musi udostępnić pracodawcy, jest także aktywnym podmiotem zainteresowanym budowaniem własnego potencjału, bo dzięki temu zyskuje przewagę konkurencyjną na rynku pracy. To on, jako właściciel kompetencji, decyduje komu, których z nich i na jakich warunkach użyczy [Strużyna 2007, za: Samul 2013]. W tym kontekście jeszcze bardziej zasadne staje się wykorzystanie przez organizację systemu zarządzania kompetencjami. Daje jej to bowiem większą kontrolę nad procesami związanymi z zarządzaniem i rozwojem kapitału ludzkiego, asekurując ją przed niekorzystnymi, z jej punktu widzenia, decyzjami pracowników. Staje się to szczególnie istotne w kontekście rynku pracownika i istniejących trudności w pozyskaniu i retencji pracowników.

\section{Możliwości wykorzystania i wdrażanie systemu zarządzania kompetencjami}

\subsection{Obszary ZKL wykorzystujące system zarządzania kompetencjami}

Warunkiem umożliwiającym wykorzystanie systemu zarządzania kompetencjami jest przygotowanie opisu stanowiska pracy, w którym obok tradycyjnych elementów je charakteryzujących umieszcza się profil kompetencyjny. Aby go stworzyć, dokonuje się m.in. analizy materiałów kadrowych, bada się dokumenty archiwalne, prowadzi się bezpośrednią obserwację pracownika, wywiady pogłębione oraz badania ankietowe wśród pracowników i kadry zarządzającej [Rostkowski (red.) 2004, s. 48-49]. Przygotowany profil jest punktem odniesienia do realizowania dalszych zadań w ramach zarządzania kapitałem ludzkim.

Do pierwszych z nich należy rekrutacja i selekcja kandydatów, a system kompetencyjny pozwala na określenie braków kompetencyjnych zespołów i poszukiwanie takich kandydatów, którzy pozwolą je zniwelować. Ponadto profil kompetencyjny przypisany do danego stanowiska pozwala precyzyjnie określić oczekiwania wobec kandydata do pracy, a jasne ich opisanie już na etapie ogłoszenia powoduje autoewaluację dokonaną przez potencjalnych kandydatów. Dzięki niej często unika się składania aplikacji niespełniających wymogów wstępnych [Wieczorek 2008, s. 68]. Następnie, w wyniku przeprowadzonej oceny selekcyjnej, zmierzone kompetencje każdego z kandydatów można porównać z profilem kompetencyjnym. Umożliwia to 
opracowanie rankingu osób ubiegających się o pracę, a wybór staje się mniej obciążony zniekształceniami decyzyjnymi. Niezmiernie ważne jest także, aby kandydata nie cechowała nadkompetencyjność, bo przyczyni się to do rozczarowania wynikającego z niskiego poziomu wyzwań zawodowych i w wielu przypadkach doprowadzi do zmiany przez niego pracy przy nadążającej się okazji [Sidor-Rządkowska 2011, s. 134].

Drugim obszarem, w którym wykorzystywane są profile kompetencyjne, jest ocenianie pracowników, w ich przebiegu diagnozuje się potencjał i dzięki temu można prognozować przyszłe rezultaty ocenianych, podejmować decyzje dotyczące ich przyszłości [Filipowicz 2014, s. 243]. Ważne jest zidentyfikowanie mocnych i słabych stron kompetencji pracownika i - postępując wbrew utartej opinii - nieskupianie się na niedostatkach kompetencyjnych, bowiem takie działanie co prawda zapobiega kryzysom, ale nie buduje przewagi konkurencyjnej. Ważne jest natomiast wzmacnianie mocnych stron pracowników, gdyż dopiero to zapewni pozytywne rezultaty organizacji. Natomiast dobór metod szkoleniowych służących rozwojowi kompetencji jest uzależniony od wielu czynników, m.in. rodzaju kompetencji, preferencji pracownika, etapu kariery [Kowlaczyk 2014]. Należy równocześnie pamiętać, że w myśl koncepcji kapitału ludzkiego odpowiedzialność za rozwój ponosi zarówno organizacja, jak i pracownik. W związku z czym ten drugi powinien mieć znaczący wpływ na dobór zakresu i metod szkoleń.

Drażliwym obszarem jest wynagradzanie za kompetencje (w porównaniu z wynagradzaniem za zajmowane stanowisko). Wynika to z faktu, iż trzeba wytypować te $\mathrm{z}$ nich, które są kluczowe dla organizacji, pomijając osiągane efekty i koncentrując się na posiadanym potencjale oraz możliwościach. Pracownicy, wiedząc, za co są wynagradzani, mają kontrolę nad poziomem swoich dochodów, a zespoły, w których pracują, stają się bardziej elastyczne i nie boją się podejmowania ryzyka obarczonego niepowodzeniem [Moczydłowska 2008], bowiem potknięcie nie spowoduje obniżenia ich zysków. Jednakże przy osiągnięciu najwyższego poziomu kompetencyjności i braku możliwości dalszego ich rozwoju osiąga się równocześnie górny próg wynagrodzenia, co stać się może de facto demotywujące.

Z kolei planowanie karier oparte na kompetencjach pokazuje pracownikowi, jakie są wymagania związane ze zmianą stanowiska pracy. Umożliwia to pracownikowi kontrolę własnej drogi rozwoju zawodowego, pomaga zaplanować, często przy pomocy doradcy zawodowego, wizję i strategię na najbliższe lata. Organizacja dzięki systemowi zarządzania kompetencjami może natomiast zaplanować sukcesje, przesunięcia stanowiskowe, lepiej motywować pracowników. W tym celu plany dotyczące rozwoju zawodowego powinny obejmować określenie aktualnego poziomu posiadanych przez pracownika kompetencji, listę stanowisk, które może on w przyszłości objąć, i wykaz kompetencji na nich wymaganych oraz krótko- i długoterminowe plany doskonalenia kompetencji pracownika [Filipowicz 2014]. W części empirycznej tego artykułu zostaną ukazane opinie kierowników na temat zasadności wykorzystania systemu zarządzania kompetencjami w poszczególnych obszarach ZKL. 
Patrycja Błocisz, Elżbieta Kowalczyk

\subsection{Warunki skutecznego wdrażania}

Warto podkreślić, że wykorzystanie systemu zarządzania kompetencjami dla wielu organizacji wiąże się innowacją w zarządzaniu kapitałem ludzkim i wymaga przygotowania metodycznego wdrożenia. Wiele jest przesłanek, które wpływają na decyzję wdrożeniową w omawianym zakresie. Od tych związanych z chęcią zdobycia przewagi konkurencyjnej, przez usprawnienie systemu zarządzania, po mobilizację pracowników do rozwoju. Przy czym P. Sparrow i J. Pickard uważają, że system kompetencyjny można wdrożyć, gdy [Nikodemska 2016]:

- możliwe jest określenie, które z kompetencji są wymagane do osiągania określonych rezultatów,

- lista kluczowych kompetencji jest ograniczona,

- istnieje widoczna zależność pomiędzy poziomem posiadanych przez pracowników kompetencji a uzyskiwanymi przez nich wynikami,

- rozwój organizacji uzależniony jest od pozyskania nowej wiedzy i umiejętności,

- rezultaty osiągane przez organizację zależą w dużej mierze od zidentyfikowanych kompetencji posiadanych przez pracowników.

Oczywiście pojawiają się pytania, na które decydenci muszą znaleźć odpowiedzi. Ważne jest między innymi: kto ma przygotować i przeprowadzić wdrożenie; kto i w jaki sposób ma skatalogować kompetencje w organizacji; jak przetwarzać informacje i czy wyodrębnić budżet na cele wdrożeniowe [Oleksyn 2006, s. 201]. Jak w przypadku każdej zmiany, aby wdrożenie systemu kompetencyjnego zakończyło się sukcesem, należy powołać profesjonalny zespół projektowy, stworzyć jasny i prosty plan wdrożeniowy, działać z dużą determinacją, przygotować działania wspierające wdrożenie (np. szkolenia, pilotaż zmiany), monitorować postępy działania i uświadamiać pracownikom ideę, zasady, korzyści nowego rozwiązania [Beck 2006]. To właśnie ten ostatni element uważa się za kluczowy dla całego procesu, a komunikowanie powinno przebiegać systematycznie z odpowiednią dbałością o precyzję informacji.

Kluczowe jest podjęcie decyzji, czy wdrożenie ma odbywać się z wykorzystaniem metody eksperckiej, czy partycypacyjnej. Pierwsza z nich opiera się na scedowaniu prac związanych z wprowadzaną zmianą na firmę zewnętrzną (z czego, jak wynika z ogólnopolskich badań, korzysta 17,1\% organizacji [Sienkiewicz, Trawińska-Konador, Podwójcic 2013, s. 43]), druga opiera się na aktywnym udziale zainteresowanych pracowników. W tym ostatnim przypadku na nich spoczywa główna odpowiedzialność za powodzenie projektu, przy czym zaangażowanie pracowników ułatwia akceptację przyjętych rozwiązań i bardzo szybkie wprowadzenie ich w życie. Jednakże i w przypadku pierwszej z metod pracownicy, zwłaszcza kierownicy, są angażowani w pracę, chociaż w znacząco mniejszym zakresie. W części empirycznej tej pracy zostały ukazane opinie kadry zarządzającej dotyczące warunków skutecznego wdrażania analizowanego systemu. 


\section{Metodyka badań własnych - narzędzia, grupa badawcza, problemy badawcze}

W przeprowadzonych, na przełomie roku 2016 i 2017, badaniach empirycznych wykorzystano ankietę on-line, która składała się 24 pytań zgrupowanych w czterech obszarach.

Grupę respondentów stanowiło 46 kierowników (średnia wieku 37 lat), którzy spełniali warunek brzegowy dotyczący wykorzystywania w ich organizacji systemu zarządzania kompetencjami. Do badania pozyskano ich poprzez kontakty networkingowe oraz zawodowe portale społecznościowe, takie jak Liknedin.com czy Goldenline.pl. Charakterystyka badanych zawarta jest w tabeli 1.

Tabela 1. Charakterystyka grupy badawczej

\begin{tabular}{|c|c|c|}
\hline \multicolumn{2}{|r|}{ Parametry } & \% ważnych \\
\hline \multirow[t]{2}{*}{ Płeć } & kobiety & 46 \\
\hline & mężczyźni & 54 \\
\hline \multirow[t]{3}{*}{ Szczebel zarządzania } & kierownik niższego szczebla & 20 \\
\hline & kierownik średniego szczebla & 52 \\
\hline & kierownik wyższego szczebla & 28 \\
\hline \multirow{4}{*}{$\begin{array}{l}\text { Staż pracy na stanowisku } \\
\text { kierowniczym }\end{array}$} & poniżej roku & 9 \\
\hline & od roku do 3 lat & 20 \\
\hline & od 3 lat do 10 lat & 41 \\
\hline & powyżej 10 lat & 30 \\
\hline \multirow{4}{*}{$\begin{array}{l}\text { Liczba podległych } \\
\text { pracowników }\end{array}$} & poniżej 10 pracowników & 47 \\
\hline & od 10 do 29praconików & 34 \\
\hline & od 30 do 50 pracowników & 12 \\
\hline & powyżej 50 pracowników & 7 \\
\hline \multirow{4}{*}{$\begin{array}{l}\text { Wielkość organizacji, } \\
\text { w której pracowali respondenci }\end{array}$} & $<9$ pracowników & 9 \\
\hline & 10-49 pracowników & 26 \\
\hline & 50-249 pracowników & 17 \\
\hline & $>250$ pracowników & 48 \\
\hline \multirow[t]{3}{*}{ Sektor działalności } & handel & 46 \\
\hline & usługi (w tym IT, edukacja, finanse, logistyka) & 44 \\
\hline & inne (w tym produkcja, administracja) & 10 \\
\hline
\end{tabular}

Źródło: badania własne.

Przeprowadzony sondaż diagnostyczny miał przynieść odpowiedzi na następująco sformułowane problemy szczegółowe:

1. Jak kadra zarządzająca definiuje kompetencje zawodowe?

2. W jakich obszarach zarządzania kapitałem ludzkim kadra zarządzająca wykorzystuje kompetencje zawodowe?

3. W jaki sposób przebiega wdrożenie systemu kompetencyjnego?

4. Jaka jest ocena użyteczności systemu w opinii kierowników? 


\section{Opinie kierowników na temat systemu zarządzania kompetencjami wraz z dyskusją wyników}

\subsection{Definiowanie kompetencji}

W pierwszej kolejności postanowiono zbadać, w jaki sposób badani rozumieją pojęcie „kompetencje”. Konstruując pytanie, umożliwiono badanym wybór trzech spośród ośmiu parametrów, które w sposób najtrafniejszy oddawały według badanych istotę tego pojęcia.

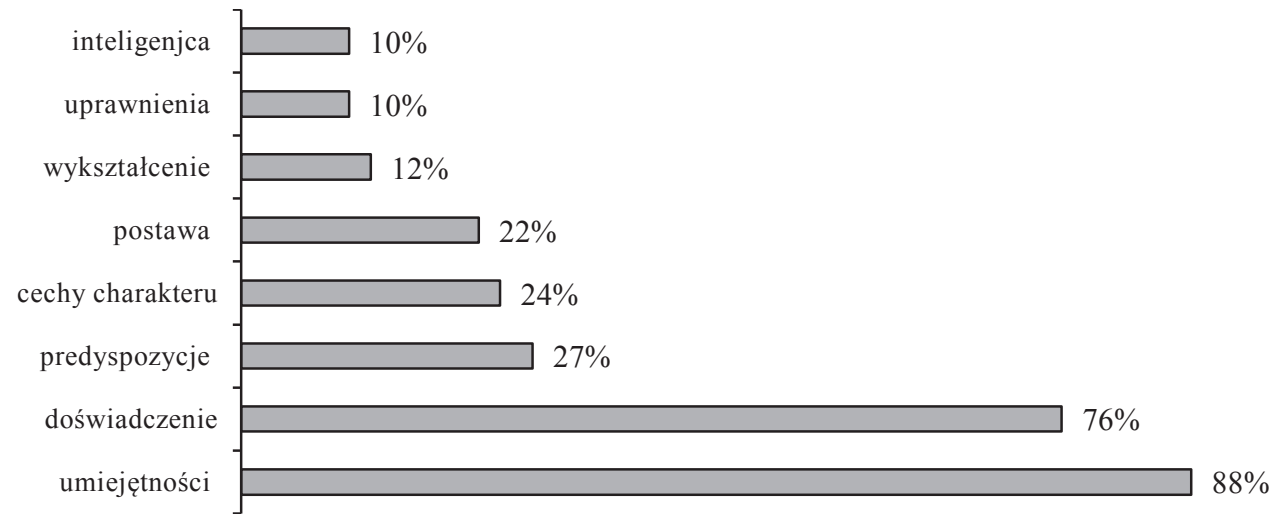

Rys. 1. Składowe kompetencji według badanych kierowników

Źródło: badania własne.

Jak można zauważyć (rys. 1), kierownicy szczególnie utożsamiają kompetencje z umiejętnościami i doświadczeniem. Natomiast w najmniejszym stopniu z inteligencją, uprawnieniami i wykształceniem. Co ciekawe, w opinii badanych mało istotne jest wykształcenie, a to ono stanowi (obok doświadczenia) składową wiedzy pracownika, uznawaną za źródło przewagi konkurencyjnej. Zatem można wnioskować, że wiedza pracowników jest w opinii kierowników głównie nabywana w trakcie praktyki zawodowej. Potwierdzają to badania nad rekrutacją pracowników, które wskazują edukację jako czynnik dalszego rzędu wpływający na decyzję o zatrudnieniu kandydata [Kowalczyk 2011].

\subsection{Obszary wykorzystywania systemu zarządzania kompetencjami}

Kolejnym krokiem badawczym było ustalenia w jakich obszarach ZKL wykorzystywany jest system kompetencyjny (rys. 2).

Jak wynika z rysunku 2, system zarządzania kompetencjami jest powszechnie stosowany w rekrutacji i selekcji, ocenach pracowniczych oraz opisie stanowisk. 

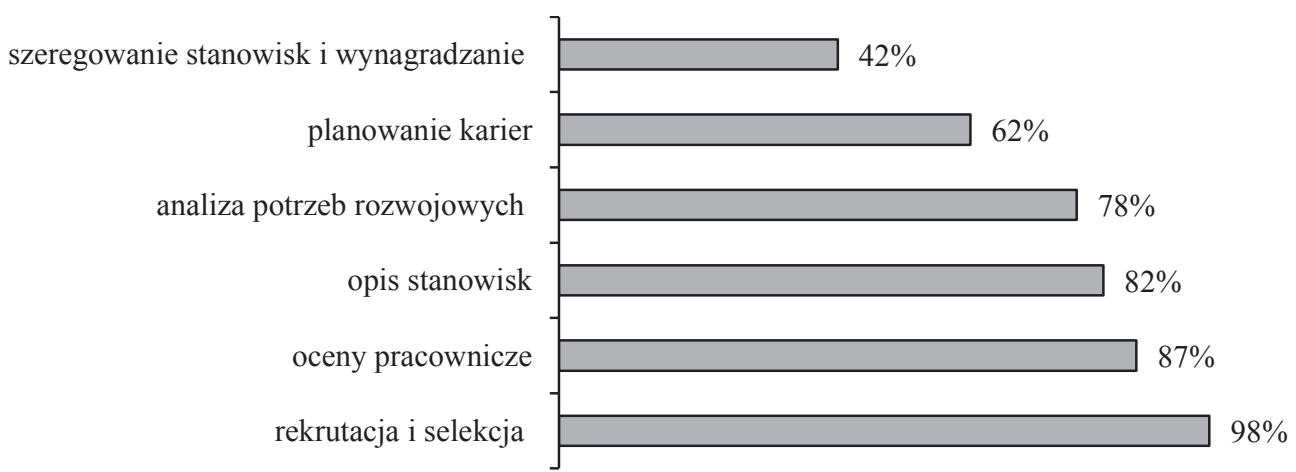

Rys. 2. Wykorzystanie systemu zarządzania kompetencjami

Źródło: badania własne.

Natomiast istnieje niedosyt $\mathrm{w}$ implantowaniu go do szeregowania stanowisk i w wynagradzaniu. Jest to niezupełnie zgodne z wynikami innych badań, które wskazują, że systemy kompetencyjne w najmniejszym stopniu firmy wykorzystują do planowania karier $(27,2 \%)$, ocen okresowych $(47,9 \%)$ oraz wynagradzania $(56,1 \%)$. Z przytoczonych badań wynika, że średni stopień wykorzystania systemu jest mniejszy aniżeli w badaniach autorek tego opracowania [Sienkiewicz, Trawińska-Konador, Podwójcic 2013].

W tabeli 2 ukazano opinie tych spośród kierowników, którzy stosują zarządzanie kompetencjami w poszczególnych obszarach, a dotyczące korzyści, jakie organizacja czerpie z systemu zarządzania kompetencjami. Jak z niej wynika, najwięcej wątpliwości budzi wynagradzanie oparte na kompetencjach, jedynie połowa spośród kierowników je stosujących uważa, że jest to rozwiązanie sprawiedliwe.

Tabela 2. Opinie kierowników na temat zalet systemu opartego na kompetencjach

\begin{tabular}{|l|c|}
\hline \multicolumn{1}{|c|}{$\begin{array}{c}\text { Kierownicy stosujący system kompetencyjny } \\
\text { w poszczególnych obszarach uważają, że sprzyja to: }\end{array}$} & \% ważnych \\
\hline Trafniejszemu wyborowi kandydata podczas rekrutacji & 87 \\
\hline Dokonaniu bardziej miarodajnej oceny pracowniczej & 84 \\
\hline Zwiększeniu świadomości stawianych wymagań & 92 \\
\hline Usprawnieniu procesu planowania działań rozwojowych & 85 \\
\hline Usprawnieniu procesu planowania kariery & 85 \\
\hline Sprawiedliwemu wynagradzaniu & 50 \\
\hline
\end{tabular}

Źródło: badania własne.

Warto zauważyć, że wprowadzenie systemu zarządzania kompetencjami jest na tyle pracochłonne, że organizacje decydujące się na niego wykorzystują go na ogół w kilku, a nie jednym obszarze zarządzania kapitałem ludzkim. W 4 z 6 obszarów 
(wymienionych na rys. 2) wykorzystuje go $29 \%$ organizacji, w 5 i 6 obszarach po $24 \%$, w $3-13 \%$, w $2-7 \%$, a w 1 zaledwie $2 \%$ organizacji.

W przytaczanych już wyżej badaniach respondenci wskazywali, że w wyniku wprowadzanego systemu w wymiarach funkcjonowania pracowników (m.in. motywacja, kreatywność, retencja) następuje zdecydowana i niewielka poprawa wahająca się od $56 \%$ do $66 \%$. Widoczny jest zatem większy sceptycyzm badanych dotyczący korzyści płynących z tego systemu [Sienkiewicz, Trawińska-Konador, Podwójcic 2013].

\subsection{Przebieg wdrożenia}

W opinii kierowników wdrożenie systemu kompetencyjnego trwało na ogół od 3 miesięcy do roku (52\%), w $24 \%$ badanych organizacji trwało powyżej roku, w $10 \%$ krócej niż 3 miesiące, a 14\% respondentów nie potrafiło udzielić odpowiedzi na to pytanie. Świadczy to o czasochłonności procesu, co stanowi jedno z większych wyzwań dla organizacji. Ponadto zaledwie w $19 \%$ przypadków było ono prowadzone przez firmę zewnętrzną, a w pozostałych $81 \%$ organizacja samodzielnie je przygotowała. Ponieważ o skuteczności wdrażania zmian w ogromnym stopniu decyduje sposób komunikowania o planach warto przyjrzeć się praktykom organizacyjnym w tym obszarze. Otóż w 48\% o wdrażaniu zmian informował kierowników prezes zarządu, w 43\% dział HR/dział personalny, a jedynie w 10\% informacja docierała przez kierownika wyższego szczebla. Ponadto kierownicy w różnym zakresie brali udział i byli przygotowywani do wprowadzenia systemu zarządzania kompetencjami, co przedstawiają rysunki 3 i 4.

Udział w pracach wdrożeniowych oraz fakt, że jedynie 15\% kierowników nie było w żaden sposób przygotowanych do pracy w oparciu o nowy system, zaowocowały pozytywnymi opiniami (74\%) na temat przejrzystości, zrozumiałości i łatwości posługiwania się nim. Jedynie w $26 \%$ przypadków kierownicy twierdzili, że system jest skomplikowany i trudno się nim posługiwać, przy czym aż $83 \%$ spośród nich nie
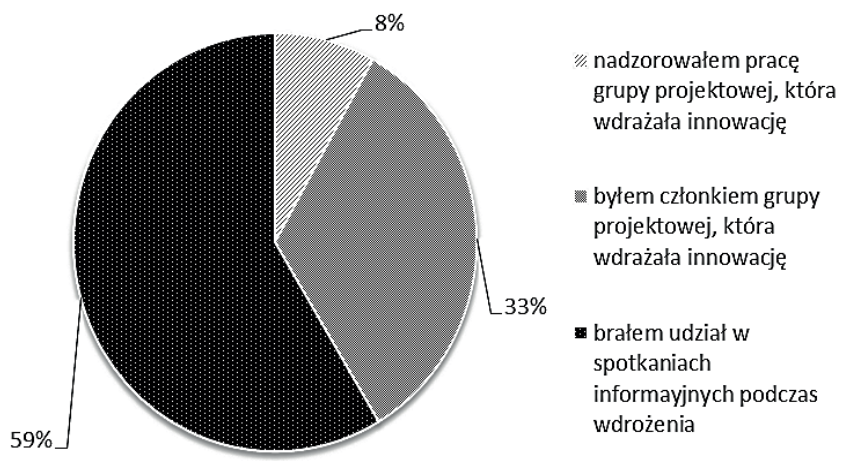

Rys. 3. Charakter udziału kierowników we wdrożeniu

Źródło: badania własne. 

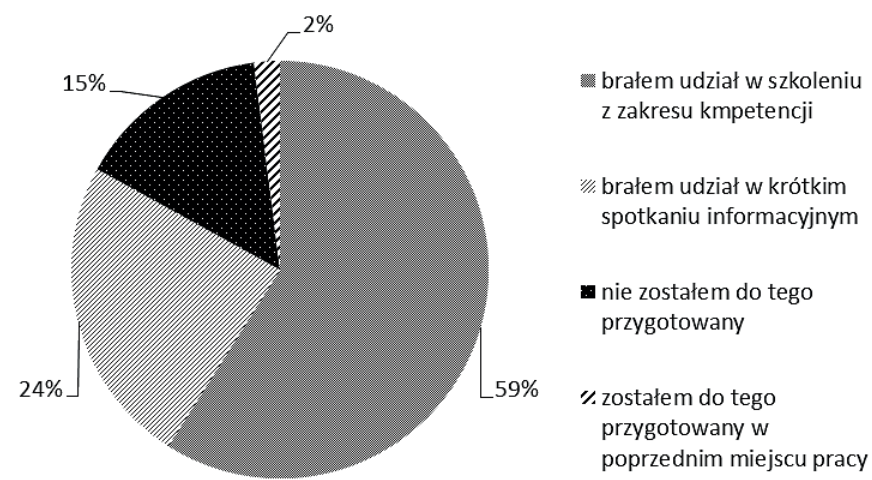

Rys. 4. Sposób przygotowania kierowników do pracy w oparciu o system kompetencyjny Źródło: badania własne.

brało czynnego udziału we wdrażaniu ani nie było przygotowanych przez organizację do posługiwania się nim. Natomiast gdy system wdrażała firma zewnętrzna, to w $80 \%$ przypadków angażowano kierowników w prace wdrożeniowe. To właśnie jasna komunikacja, zaangażowanie kierowników w prace wdrożeniowe i przygotowanie do wykorzystania nowego narzędzia zarządczego jest czynnikiem determinującym sukces przeprowadzanej zmiany. Równocześnie z przytaczanych już wcześniej badań wynika, że główne obiekcje wobec tego rozwiązania wynikają z braku właściwej komunikacji i przekazania wiedzy na temat planowanej zmiany [Sienkiewicz, Trawińska-Konador, Podwójcic 2013].

\subsection{Opnie kierowników na temat wykorzystania systemu kompetencyjnego}

Spośród różnych efektów, jakie niesie za sobą wykorzystanie systemu zarządzania opartego na kompetencjach, wybrano cztery aspekty, do których badani ustatkowywali się na 5-stopniowej skali typu Likerta (od 1 - ,zdecydowanie nie zgadzam się", do 5 - „zdecydowanie zgadzam się”). Uzyskane dane zawarte są w tabeli 3.

Tabela 3. Opinie kierowników dotyczące przydatności wykorzystania kompetencji w ZKL

\begin{tabular}{|c|c|c|c|c|c|c|}
\hline \multirow{2}{*}{$\begin{array}{l}\text { Wykorzystanie systemu zarządzania kompetencjami } \\
\text { wpływa na: }\end{array}$} & \multicolumn{5}{|c|}{ Skala Likerta } & \multirow{2}{*}{$\begin{array}{l}\text { Średnia } \\
\quad(M)\end{array}$} \\
\hline & 1 & 2 & 3 & 4 & 5 & \\
\hline 1. Poprawę wyników podl & $0 \%$ & $0 \%$ & $15 \%$ & $46 \%$ & $39 \%$ & 4,24 \\
\hline 2. Wzrost zaangażowania podległych pracowników & $0 \%$ & $4 \%$ & $28 \%$ & $33 \%$ & $35 \%$ & 3,98 \\
\hline 3. Rozwój członków zespołu & $0 \%$ & $4 \%$ & $11 \%$ & $59 \%$ & $26 \%$ & 4,07 \\
\hline $\begin{array}{l}\text { 4. Ułatwienie przygotowania podległego zespołu } \\
\text { do bieżących oraz przyszłych zmian }\end{array}$ & $0 \%$ & $7 \%$ & $24 \%$ & $41 \%$ & $28 \%$ & 3,91 \\
\hline Ogólnie: & $0 \%$ & $4 \%$ & $20 \%$ & $45 \%$ & $32 \%$ & 4,05 \\
\hline
\end{tabular}

Źródło: badania własne. 
Większość z badanych „zgadza się” i „zdecydowanie zgadza się”, że system zarządzania oparty na kompetencjach przyczynia się do pozytywnych efektów w zakresie zarządzania kapitałem ludzkim. Szczególnie poprawia wyniki zespołu i sprzyja rozwojowi jego członków. Równocześnie im w większej liczbie obszarów system jest wykorzystywany, tym kierownicy dostrzegali jego większą użyteczność (od $M=3,63 \mathrm{w}$ jednym obszarze do $M=4,35$ przy wykorzystaniu w 6 obszarach). Warto podkreślić, że tylko $4 \%$ kierowników nie poleca tego rozwiązania, $17 \%$ nie ma zadania, natomiast aż 78\% jednoznacznie je rekomenduje.

\section{Zakończenie}

W wyniku przeprowadzonych badań autorki ustaliły, że prace związane z wdrażaniem systemu zarządzania kompetencjami przynoszą pozytywne rezultaty, lecz muszą być przygotowane i wdrożone zgodnie z zaleceniami specjalistów. Ponadto wprowadzenie wyżej analizowanej zmiany daje najlepsze wyniki, gdy wykorzystuje się ją w wielu obszarach zarządzania kapitałem ludzkim. W dobie rynku pracownika kluczem do sukcesu firmy, polegającym na pozyskaniu i retencji cennych pracowników, jest współpraca osób zarządzających nimi z samymi zainteresowanymi, którzy często chcą współdecydować o swojej ścieżce kariery i kompetencjach poddawanych rozwojowi. Przynosi to także wymierne efekty organizacji w postaci zwiększonego zaangażowania pracowników i lepszego wywiązywania się przez nich z zadań.

Poszukując odpowiedzi na wcześniej sformułowane pytania badawcze, autorki pragną jeszcze raz podkreślić:

1. kadra zarządzająca głównie utożsamia kompetencje z umiejętnościami i doświadczeniem;

2. zarządzanie oparte na kompetencjach jest wykorzystywane we wszystkich obszarach personalnych, ze szczególnym naciskiem na rekrutację i selekcję oraz prowadzenie ocen pracowniczych;

3. wdrożenie jest procesem długotrwałym, a o jego sukcesie decyduje zaangażowanie kierowników i skuteczna komunikacja;

4. wdrożenie systemu wpływa pozytywnie na rozwój pracowników, jak i efekty pracy zespołowej; na postrzeganie użyteczności wpływa kompleksowość wykorzystania systemu; jest on rekomendowany przez $78 \%$ badanych.

\section{Literatura}

Beck E., 2006, Zmiana i rozwój organizacji, [w:] Zbiegień-Maciąg L. (red.), Nowe tendencje i wyzwania w zarządzaniu personelem, Oficyna Ekonomiczna Wolters Kluwer, Kraków.

Draganidis F., Mentzas G., 2006, Competency based management: A review of systems and approaches, Information Management \& Computer Security, 14(1), s. 51-64, doi: 10.1108/09685220610648373.

Filipowicz G., 2014, Zarzadzanie kompetencjami. Perspektywa firmowa i osobista, Wolters Kluwer, Warszawa. 
Kowalczyk E., 2011, Proces negocjacji w sprawie pracy. Aspekty psychospołeczne i organizacyjne, Wydawnictwo Uniwersytetu Ekonomicznego w Poznaniu, Poznań.

Kowlaczyk E., 2014, Człowiek, organizacja, kariera. Siła psychologii stosowanej, Difin, Warszawa.

Moczydłowska J.M., 2008, Zarzadzanie kompetencjami zawodowymi a motywowanie pracowników, Difin, Warszawa.

Nikodemska S., 2016, ABC kompetencji, Warszawa, https://www.slideshare.net/emplocom/bezpatnyebook-abc-kompetencji-50-stron-dla-eksperta-hr-2016-02-11 (22.02.2018).

Oleksyn T., 2006, Zarzadzanie kompetencjami, Oficyna Ekonomiczna, Kraków.

Orlińska-Gondor A., 2006, Zarządzanie ludźmi oparte na pojęciu kompetencji, [w:] Zbiegień-Maciąg L. (red.), Nowe tendencje $i$ wyzwania w zarzadzaniu personelem, Oficyna Ekonomiczna Grupa Wolters Kulwer, Kraków, s. 168-190.

Rostkowski T. (red.), 2004, Nowoczesne metody zarządzania zasobami ludzkimi, Difin, Warszawa.

Samul J., 2013, Definicje kapitału ludzkiego w ujęciu porównawczym, Administracja i Zarządzanie, 23(96), s. 195-204, https://repozytorium.uph.edu.pl/bitstream/handle/11331/756/Samul_Definicje_kapitalu_ludzkiego.pdf? sequence=1 (17.02.2018).

Sidor-Rządkowska M., 2011, Kompetencyjne systemy ocen pracowników, 2. wyd., Oficyna a Walter Kluwers business, Warszawa.

Sienkiewicz Ł., Trawińska-Konador K., Podwójcic K., 2013, Polityka zarządzania kompetencjami pracowników, Warszawa, http://biblioteka-krk.ibe.edu.pl/opac_css/doc_num.php?explnum_id=473 (23.02.2018).

Whiddett S., Hollyforde S., 2003, Modele kompetencyjne w zarzadzaniu zasobami ludzkimi, Oficyna Ekonomiczna, Kraków.

Wieczorek J., 2008, Efektywne zarządzanie kompetencjami - tworzenie przewagi konkurencyjnej firmy, Ośrodek Doradztwa i Doskonalenia Kadr Sp. z o.o., Gdańsk. 